\title{
Possible Effect of Persimmon (Diospyros kaki) Fruits in Streptozotocin-Induced Diabetic Rats
}

\author{
${ }^{1}$ Heba M. A. El-Tour and ${ }^{2}$ Nahed A. A. El-Wahsh \\ ${ }^{1}$ Faculty of Agriculture, Alexandria University, Egypt - ${ }^{2}$ Dairy Science \\ Department, Food Science and Technology Institute, Research Center Institute, \\ Giza
}

\section{Abstract}

The effects of different concentrations (2, 4 and $6 \%$ ) of persimmon fruits (Diospyros kaki) powders on diabetic rats was evaluated. Thirty Albino rats weating $140 \pm 10 \mathrm{~g}$ were used in this study and divided into 5 groups, each group contain 6 rats. Rats were treated by streptozotocin $(40 \mathrm{mg} / \mathrm{kg} \mathrm{B} . \mathrm{W})$ to induced diabetic. Results showed that the highest body weight gain, feed intake and feed efficiency ratio recorded for $6 \%$ persimmon fruits, while the lowest recorded for $2 \%$ persimmon fruits with no significant difference. Rat groups fed on $6 \%$ persimmon fruit recorded the highest liver, kidney and spleen weight. Rats fed on $6 \%$ persimmon fruit recorded the lowest glucose level with a significant difference being, $97.53 \mathrm{mg} / \mathrm{dl}$. The lower ALT, AST and ALP liver enzyme of treated group which recorded for group fed on $6 \%$ persimmon fruits, but the highest value recorded for group fed on $2 \%$ persimmon fruits with a significant difference. Lowest value of triglyceride and cholesterol recorded for group fed on $6 \%$ persimmon fruit. The highest HDL-c of treated group recorded for group fed on $6 \%$ persimmon fruits. While, the highest LDL-c and VLDL-c of treated group recorded for rats fed on $2 \%$ persimmon fruits. The highest urea and uric acid levels of treated group which recorded for group fed on 4 $\%$ persimmon fruits. While, the lowest creatinine level of treated group which recorded for group fed on $6 \%$ persimmon fruits. As conclusion, $6.0 \% \%$ persimmon fruits as powder recorded the best levels for improvement glucose levels, lipid profile, liver functions and kidney functions. Therefore, $6.0 \% \%$ persimmon fruits as powder could be used in our drinks and many dishes.

Key words: Anti-diabetic, Persimmon fruits, Rats, and Biochemical analysis. 
التأثير المحتمل لثمار الكاكى فى الفئرلن المصابة بالسكر المستحث

\section{بالأستريتوسيتوكين}

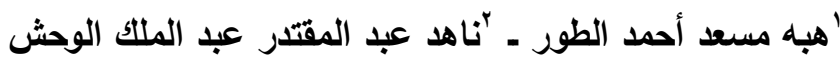

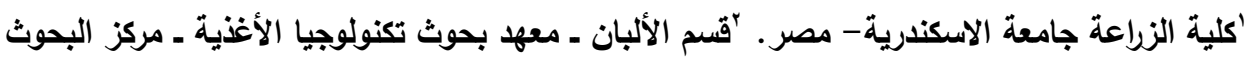

$$
\text { الزراعية ـ الجيزة. }
$$

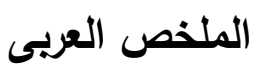

تم دراسـة تأثثر تركيزات مختلفـة (؟، ع، ؟\%) مـن مسـحوق ثمـار الكـاكي في الفئران

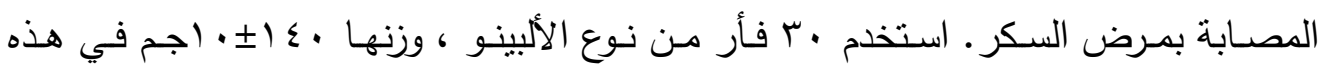

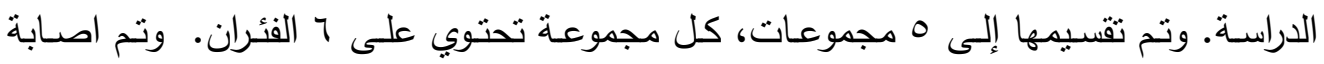
الفئران ( •ـ مجم/ كجم من وزن الجسم) بمرض السكر بواسطة الأستربتوسيتوكين .وأظهرت

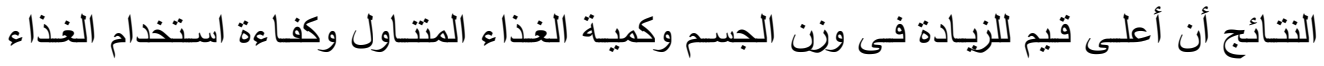

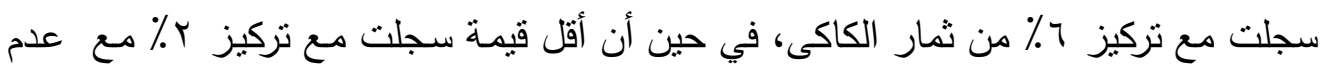

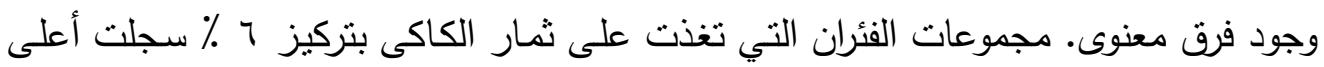

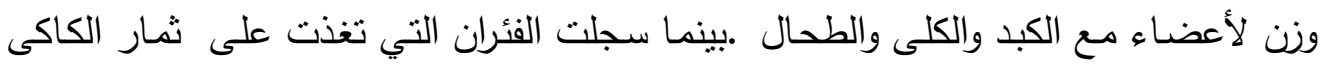

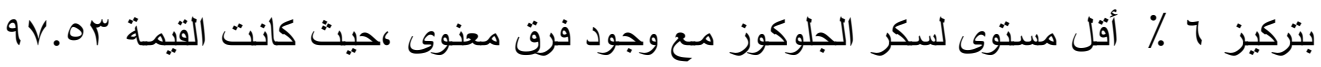

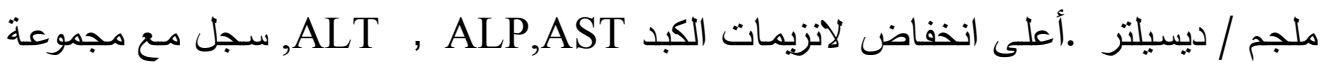

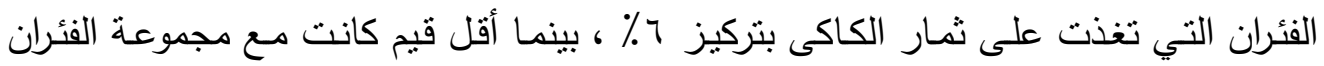

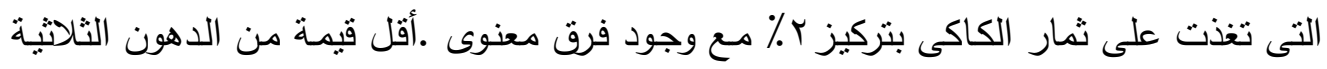

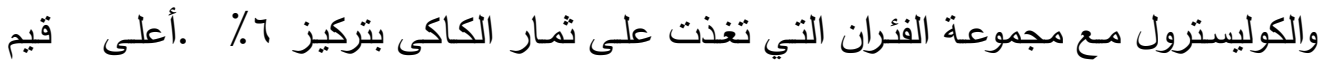

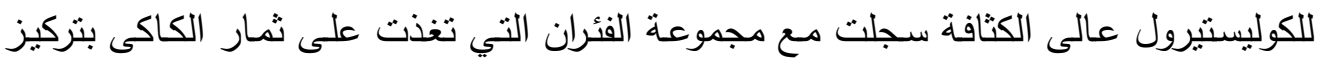



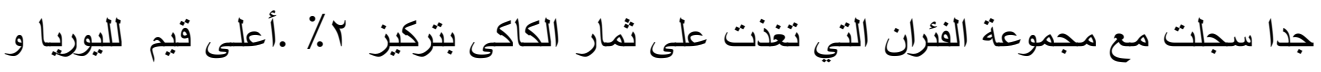

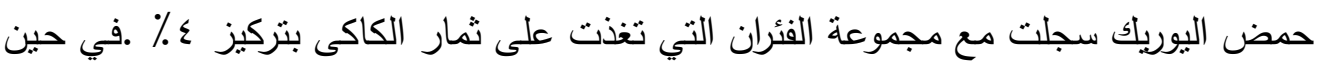

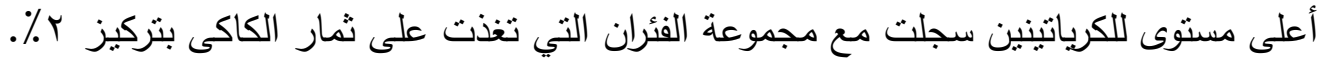

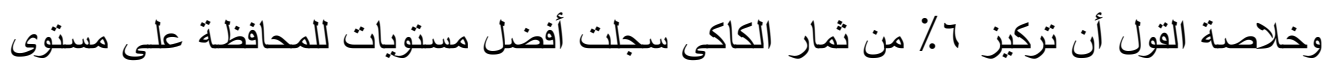
الجلوكوز وصحة الكبد، وتحسين صورة دهون الدم ووظائف الكلى. ويمكن التوصية بأستخدام مسحوق الكاكى فى بعض المشروبات أو اضافته إلى بعض الوضن الوجبات الغذائية. الكلمات الكاشفة: التأثير المضاد للسكر ـ ثمار الكاكى ـ الفئران ـ التحاليل الكيميائية الحيوية. 


\section{Introduction}

Diabetes is a group of metabolic diseases characterized by hyperglycemia resulting from defects in insulin secretion, insulin action, or both. The chronic hyperglycemia of diabetes is associated with longterm damage, dysfunction, and failure of different organs, especially the eyes, kidneys, nerves, heart, and blood vessels. Several pathogenic processes are involved in the development of diabetes. These range from autoimmune destruction of the pancreatic $\beta$-cells with consequent insulin deficiency to abnormalities that result in resistance to insulin action (American Diabetes Association, 2014).

Since, ancient times, plants have played an important role in the treatment of many diseases. Different parts of medicinal plants such as leaf, root, flower and seed are used as extracts and chemical compounds to produce drugs (Ozgen et al., 2009).

The prevalence of diabetes is increasing rapidly worldwide has predicted that by 2030 the number of adults with diabetes would have all most doubled worldwide, from 177 million in 2000 to 370 million. Experts project that the incidence of diabetes is set to soar by $64 \%$ by 2025. There are two main types of diabetes mellitus: Type1 diabetes also called insulin dependent diabetes mellitus (IDDM), is caused by lack of insulin secretion by beta cell of the pan crease. Type 2 diabetes, also called non - insulin dependent diabetes mellitus (NIDDM), is caused by decreased sensitivity of target tissues to insulin (Rowley and Bezold, 2012).

Diabetes is any disorder characterized by excessive urine excretion. The most common form of diabetes is Diabetes mellitus, a chronic, progressive, systematic condition of impaired carbohydrate metabolism (Sachan et al., 2009).

Diabetes is the world's largest endocrine disease associated with increased morbidity and mortality rate. Diabetes mellitus is also associated with long term complications including retinopathy, nephropathy, neuropathy and angiopathy and several others (Sharma et al., 2010).

Medicinal plants are gradually gaining global acceptability given their potential as bioactive agents to be used as pharmaceuticals. New hypoglycemic agents derived from plants have shown both hypoglycemic action and the ability to improve some of the secondary complications of diabetes such as kidney damage, fatty liver, and oxidative stress. In addition, some tropical herbs offer both benefits as it has been recently informed in experimental models (Fonseca et al., 2012). 
The health promoting potential of persimmon includes its effectiveness against free-radical production, hypercholesterolemia, diabetes mellitus, cancer, dermal disorders, hypertension, etc. This review is an attempt to elucidate the phytochemistry of persimmon and importance of its bioactive molecules in curing various health disparities (Butta et al., 2015).

Bioactive compounds particularly phenolics (ferulic, p-coumaric, and gallic acids) and carotenoids ( $\beta$-cryptoxanthin, lycopene, $\beta$ carotene, and lutein) are of major interests in persimmon fruit. These valued bioactive components have strong antioxidant potential which relates to the variety, stage of maturity, and fruit parts. These functional compounds can play a significant role in preventing and curing various ailments like diabetes, hypercholesterolemia, and cancer (Yaqub et al., 2016).

Among the fruits, persimmon (Diospyros kaki) is a popular and widespread fruit that is enriched with many bioactive compounds, including polyphenols, terpenoids, steroids, flavonoids, carotenoids, minerals, and dietary fiber. Some components like phenolics, antioxidants, sterols, and flavonoids have a beneficial effect on human health owing to their ability to prevent or control various ailments (Karaman et al., 2014).

Persimmon (Diospyros kaki L.) is an important horticultural crop which has many cultivated varieties. Based on the statistics of FAO, the annual production of persimmon in China is about 2.68 million tons, accounting for about $70.0 \%$ of the total world production ( FAO, 2010).

Persimmon fruit contains different nutrients and phytochemicals such as carbohydrates, organic acids, vitamins, tannins, polyphenols, dietary fibers and carotenoids etc., which play important roles in the flavor, color, nutritive and pharmaceutical value of the fruit (Celik et al., 2007).

Persimmons revealed considerable health and medicinal benefits, which are considered to be related to the various hydrophilic and lipophilic antioxidants including phenolic compounds, vitamin $\mathrm{C}$ and carotenoids, contained in the fruit (George and Redpath, 2008).

Traditionally, persimmon fruit have been used for their medicinal properties, such as their blood pressure-lowering and diuretic effects. A persimmon supplemented diet had a lipid-lowering effect and positively influenced organ functions in streptozotocin induced diabetic rats. Persimmon fruit improved also lipid metabolism in rats fed diets 
containing cholesterol and showed antigenotoxic effect . Furthermore, persimmon has been shown to have antitumor properties on several tumor cell lines in vitro and has been associated with an inhibitory effect on human lymphoid leukemia cells (Quan et al., 2012).

Azadbakhta et al., (2010) demonstrate that aqueous fruits extracts of D. kaki, L. possesses anti-diabetic properties suggesting the presence of biologically active components which may be worth further investigation and elucidation. The effective anti-diabetic dose was also found to be $1000 \mathrm{mg} / \mathrm{kg}$ body weight. These results suggest that the product of $D$. kaki, L. may provide a new therapeutic avenue against diabetes and diabetes-related complications a global burden.

\section{Material and methods \\ Materials:}

A persimmon (Diospyros kaki) fruit was obtained from local market, Shibin El-Kom City, Menoufia Governorate, Egypt. Streptozotocin, it was pure chemical fine product (DBH) were purchased from SIGMA Chemical Co., (USA), and was used for induction of diabetes among rats. Casein, cellulose, choline chloride powder, and DL methionine powder, were obtained from Morgan Co. Cairo, Egypt. Chemical kits used for determination the (TC, TG, HDLc, ALT, AST, ALP, urea, uric acid and creatinine) were obtained from Al-Gomhoria Company, Cairo, Egypt.

\section{Experimental animals:}

A total of 30 adult normal male albino rats Sprague Dawley strain weighing $140 \pm 10 \mathrm{~g}$ were obtained from Vaccine and Immunity Organization, Ministry of Health, Helwan Farm, Cairo, Egypt.

\section{Methods:}

\section{Preparations of persimmon fruit:}

To prepare the dried persimmon fruit was obtained from local market. Fruits were washed thoroughly under running tap water, shade dried in air over at $50^{\circ} \mathrm{C}$, and ground to a fine powder using an air mill.

\section{Experimental design:}

Thirty adult male white albino rats, Sprague Dawley Strain, 10 weeks age, weighing $(140 \pm 10 \mathrm{~g})$ were used in this experiment. All rats were fed on basal diet (casein diet) prepared according to AIN, (1993) for 7 consecutive days. After this adaptation period, rats are divided into 5 groups, each group which consists of six rats as follows: group (I): rats fed on basal diet as negative control. 
Group (2): A group injected by streptozotocin a dose of $40 \mathrm{mg} / \mathrm{kg}$ of rat's body weight and used as a positive control group.

Group (3): A group infected diabetic fed on persimmon fruit as powder by $2 \%$ of the weight of basal diet.

Group (4): A group infected diabetic fed on persimmon fruit as powder by $4 \%$ of basal diet.

Group (5): A group infected diabetic fed on persimmon fruit as powder by $6 \%$ of basal diet. During the experimental period, the body weight and feed intake were estimated weekly and the general behavior of rats was observed. The experiment period was take 28 days, at the end of the experimental period each rat weight separately then, rats are slaughtered and collect blood samples. Blood samples were centrifuged at $4000 \mathrm{rpm}$ for ten minute to separate blood serum, and then kept in deep freezer till using.

\section{Blood sampling:}

After fasting for 12 hours, blood samples in initial times were obtained from retro orbital vein, while it obtained from hepatic portal vein at the end of each experiment. Blood samples were collected into a dry clean centrifuge glass tubes and left to clot in water bath $\left(37^{\circ} \mathrm{C}\right)$ for 30 minutes, then centrifuged for 10 minutes at $4000 \mathrm{rpm}$ to separate the serum, which were carefully aspirated and transferred into clean cuvette tube and stored frozen in deep freezer till analysis according to method described by Schermer (1967).

\section{Body weight gain (BWG), feed intake (FI), and feed efficiency ratio (FER):}

During the experimental period (28 days) the net feed intake was daily recorded, while body weight was weekly recorded. The net feed intake and gained body weight were used for the calculation of feed efficiency ratios (FER) according to Chapman et al., (1959) as follow:

$$
\text { FER } \%=\frac{\text { Body weight gain }(\mathrm{g})}{\text { Food intake }(\mathrm{g})} \times 100
$$

\section{Biochemical analysis:}

\section{Lipids profile:}

Serum total cholesterol was determined according to the colorimetric method described by Thomas (1992). Serum triglyceride was determined by enzymatic method using kits according to the Young, (1975) and Fossati, (1982). 
HDL-c was determined according to the method described by Friedewaid (1972) and Grodon and Amer (1977).

VLDL-c LDL-c were calculated according to Lee and Nieman (1996) in $\mathrm{mg} / \mathrm{dl}$ using the following formula:

VLDL-c $(\mathrm{mg} / \mathrm{dl})=$ Triglycerides $/ 5$.

LDL-c was calculated in $\mathrm{mg} / \mathrm{dl}$ as follows:

LDL-c $(\mathrm{mg} / \mathrm{dl})=$ Total cholesterol - HDL-c - VLDL-c.

\section{Liver functions:}

Determination of serum alanine amino transferase (ALT), serum asparatate amino transferase (AST), serum alkaline phosphatase (ALP) were carried out according to the method of Hafkenscheid (1979), Clinica Chimica Acta (1980), and Moss (1982), respectively.

\section{Kidney functions:}

Serum urea and serum creatinine were determined by enzymatic method according to (Henry (1974) and Patton \& Crouch 1977).

\section{Determination of blood glucose:}

Enzymatic determination of plasma glucose was carried out calorimetrically according to the method of Tinder (1969).

\section{Statistical analysis:}

The data were analyzed using a completely randomized factorial design (SAS, 1988) when a significant main effect was detected; the means were separated with the Student-Newman-Keuls Test. Differences between treatments of $(\mathrm{P} \leq 0.05)$ were considered significant using Costat Program. Biological results were analyzed by One Way ANOVA.

\section{Results and discussion}

Data given in Table (1) show the changes of body weight, feed intake and feed efficiency ratio of diabetic rats fed diet supplemented with persimmon fruits. The obtained results showed that the body weight gain (BWG) $\mathrm{g} / 28$ day of positive control recorded the highest value when compared with negative control with significant difference. The mean values were 69.7 and $50.8 \mathrm{~g} / 28$ day, respectively.

From diabetic rat groups, it is clear to notice that the highest (BWG) $\%$ recorded for $6 \%$ persimmon fruit, while the lowest BWG $\%$ recorded for $2 \%$ persimmon fruit with non-significant difference. The mean values were 55.3, 54.6 and $53.1 \mathrm{~g} / 28$ day, respectively.

In case of feed intake, it could be notice that the feed intake (FI) g/ day of positive control recorded the highest value when compared with negative control with significant difference. The mean values were 
14.48 and $13.0 \mathrm{~g} / \mathrm{day}$, respectively. While, $6 \%$ persimmon fruit recorded the highest FI while the lowest value recorded for $2 \%$ persimmon fruit with significant difference. The mean values were 14.40 and $13.98 \mathrm{~g} /$ day, respectively.

On the other hand, feed efficiency ratio (FER) of negative positive control recorded the highest value when compared with positive control with significant difference. The mean values were 0.194 and $0.172 \%$, respectively. In case of treated rat groups, it clear to mention that $10 \%$ persimmon fruits recorded the highest FER while, the lowest value recorded for 2 and $4 \%$ persimmon fruits. The mean values were 0.137 , 0.136 and $0.136 \%$, respectively. These results are in agreement with Chen and Ianuzzo (1982), they found that a significant weight loss was observed in the diabetic group and significant improvement in weight was observed in the groups treated with D. lotus, L. This may be due to the ability of $D$. lotus $L$. to reduce hyperglycemia.

Data presented in Table (2) show the changes of organs weight in the diabetic rats fed diet supplemented with persimmon fruit.

It is clear to notice that the liver weight of positive control group recorded the highest value when compared with negative control group with significant difference. The mean values were 7.12 and $6.10 \mathrm{~g}$, respectively. While, group fed on $10 \%$ persimmon fruits recorded the highest liver weight while the lowest value recorded for $7.5 \%$. The mean values were 6.62 and $6.22 \mathrm{~g}$, respectively.

On the other hand, kidney weight of positive and negative control groups recorded the same values being, $1.25 \mathrm{~g}$. While, group fed on 2 and $6 \%$ persimmon fruit recorded the highest kidney weight while the lowest value recorded for $4 \%$. The mean values were 1.125 and $0.975 \mathrm{~g}$, respectively.

In case of spleen weight, the positive and negative control groups recorded the same values being, $0.825 \mathrm{~g}$. While, group fed on $10 \%$ persimmon fruits recorded the highest spleen weight while the lowest value recorded for $7.5 \%$. The mean values were 0.850 and $0.775 \mathrm{~g}$, respectively. These results are in agreement with Ahn et al., (2002).

Data presented in Table (3) show the effect of persimmon on glucose of diabetic rats. The obtained results indicated that the highest glucose level recorded for positive control group, while the lowest level recorded for negative control group with significant differences. The mean values were 198 and $96 \mathrm{mg} / \mathrm{dl}$, respectively. 
On the other hand, rats fed on $10 \%$ persimmon recorded the lowest glucose level with significant differences being, $97.53 \mathrm{mg} / \mathrm{dl}$. While, the higher glucose level in diabetic rats recorded for $2 \%$ persimmon with significant differences. The value was $117 \mathrm{mg} / \mathrm{dl}$. It could be concluded that increasing persimmon levels showed highest reduction in glucose level. These results are in agreement with Azadbakhta et al., (2010), they reported that oral administration of D. lotus, $L$. fruits extract for 16 days effectively controlled hyperglycemia, due to the presence of biologically active components. The product of $D$. lotus, $L$. may provide a new therapeutic avenue against diabetes and diabetes-related complications a global burden.

Data given in Table (4) show the effect of persimmon on (ALT, AST and (ALP) of diabetic rats. The obtained results indicated that the ALT liver enzyme of positive control rats group recorded the highest value when compared with negative control group with significant difference. The mean values were 197.0 and $95.0 \mathrm{U} / \mathrm{L}$, respectively. While, the highest ALT liver enzyme of treated group recorded for group fed on $2 \%$ persimmon fruits but, the lowest value recorded for group fed on $10 \%$ persimmon fruits with significant difference. The mean values were 135.0 and $90.0 \mathrm{U} / \mathrm{L}$, respectively.

On the other hand, AST liver enzyme of positive control rats group recorded the highest value when compared with negative control group with significant difference. The mean values were 55.82 and $9.22 \mathrm{U} / \mathrm{L}$, respectively. While, the highest GOT liver enzyme of treated group recorded for group fed on $2 \%$ persimmon fruits but, the lowest value recorded for group fed on $6 \%$ persimmon fruits with significant difference. The mean values were 39.4 and $17.21 \mathrm{U} / \mathrm{L}$, respectively.

In case of ALP liver enzyme of positive control rats group recorded the highest value when compared with negative control group with significant difference. The mean values were 20.7 and $6.5 \mathrm{U} / \mathrm{L}$, respectively. While, the highest ALP liver enzyme of treated group recorded for group fed on $4 \%$ persimmon fruits but, the lowest value recorded for group fed on $6 \%$ persimmon fruits with significant difference. The mean values were 10.93 and $6.0 \mathrm{U} / \mathrm{L}$, respectively. These results are in agreement with Sochar et al., (1985), they reported that the persimmon fruits extract maintains the blood glucose to normoglycemia during diabetes, which acts as an essential trigger for both liver and kidney to revert to their normal metabolic homeostasis. The liver and kidney exhibits numerous morpho-logical and functional alterations during diabetes. 
The effect of persimmon fruits on the serum lipid profiles of diabetic rats are shown in Table (5). The obtained results indicated that the triglyceride of positive control group recorded the highest value when compared with negative control group with significant difference. The mean values were 223.2 and $81.3 \mathrm{mg} / \mathrm{dl}$, respectively. While, the lowest triglyceride recorded for group fed on $6 \%$ persimmon fruit while the highest value recorded for $2 \%$ persimmon fruit with significant difference. The mean values were 145.9 and $169.1 \mathrm{mg} / \mathrm{dl}$, respectively.

In the other hand, the cholesterol levels of positive control group recorded the highest value when compared with negative control group with significant difference. The mean values were 97.0 and $63.5 \mathrm{mg} / \mathrm{dl}$, respectively. While, the lowest cholesterol levels recorded for group fed on $6 \%$ persimmon fruit while the highest value recorded for $2 \%$ persimmon fruit with significant difference. The mean values were 64.6 and $72.6 \mathrm{mg} / \mathrm{dl}$, respectively. These results are in agreement with Gorinstein et al., (2000), they mention that persimmon is one of nutritious entities that hold hypocholesterolemic effects. The reasons include presence of bioactive compounds that possess the plasma lipid lowering and antioxidant properties. Also, Kim and Yoozawa (2009), they reported that the whole persimmon or its parts hold lipid lowering effects in hypercholesterolemic rats.

Data presented in Table (6) show the effect of persimmon fruit on the serum lipid profiles of diabetic rats. The results indicated that the HDL-c of negative control rats group recorded the highest value when compared with positive control group with significant difference. The mean values were 33.3 and $23.3 \mathrm{mg} / \mathrm{dl}$, respectively. While, the highest HDL-c of treated group recorded for group fed on $10 \%$ persimmon fruits but, the lowest value recorded for group fed on $2 \%$ persimmon fruits with significant difference. The mean values were 29.7 and 27.3 $\mathrm{mg} / \mathrm{dl}$, respectively.

On the other hand, the LDL-c of positive control rats group recorded the highest value when compared with negative control group with significant difference. The mean values were 29.05 and 13.94 $\mathrm{mg} / \mathrm{dl}$, respectively. While, the highest LDL-c of treated group recorded for group fed on $2 \%$ persimmon fruits but, the lowest value recorded for group fed on $6 \%$ persimmon fruits with significant difference. The mean values were 11.98 and $5.72 \mathrm{mg} / \mathrm{dl}$, respectively.

In case of VLDL-c, the positive control rats group recorded the highest value when compared with negative control group with 
significant difference. The mean values were 44.64 and $16.26 \mathrm{mg} / \mathrm{dl}$, respectively. While, the highest VLDL-c of treated group recorded for group fed on $2 \%$ persimmon fruits but, the lowest value recorded for group fed on $6 \%$ persimmon fruits with significant difference. The mean values were 33.82 and $29.18 \mathrm{mg} / \mathrm{dl}$, respectively. Matsumoto et al., (2006) supplemented diet with young persimmon fruit $(10 \%)$ that resulted in similar results i.e. lowering of total \& LDL cholesterol and triglyceride. They reported that the improvement lipid profile might be due to increase the expression of cholesterol 7 alpha-hydroxylase (CYP7A1) gene's expression. CYP7A1 regulates bile acid synthesis thus holds imperative role in balancing cholesterol homeostasis.

Data presented in Table (7) show the effect of persimmon fruits on urea, uric acid and creatinine of diabetic rats. The obtained results indicated that the urea level of positive control rats group recorded the highest value when compared with negative control group with significant difference. The mean values were 73.65 and $42.2 \mathrm{mg} / \mathrm{dl}$, respectively. While, the highest urea level of treated group recorded for group fed on $4 \%$ persimmon fruits but, the lowest value recorded for group fed on $6 \%$ persimmon fruits with significant difference. The mean values were 58.27 and $46.25 \mathrm{mg} / \mathrm{dl}$, respectively.

On the other hand, the uric acid level of positive control rats group recorded the highest value when compared with negative control group with significant difference. The mean values were 3.97 and $2.11 \mathrm{mg} / \mathrm{dl}$, respectively. While, the highest uric acid level of treated group recorded for group fed on $4 \%$ persimmon fruits but, the lowest value recorded for group fed on $6 \%$ persimmon fruits with non-significant difference. The mean values were 2.6 and $1.95 \mathrm{mg} / \mathrm{dl}$, respectively.

In case of creatinine, the level of positive control rats group recorded the highest value when compared with negative control group with significant difference. The mean values were 1.13 and $0.87 \mathrm{mg} / \mathrm{dl}$, respectively. While, the highest creatinine level of treated group recorded for group fed on $2 \%$ persimmon fruits but, the lowest value recorded for group fed on $6 \%$ persimmon fruits with significant difference. The mean values were 0.99 and $0.89 \mathrm{mg} / \mathrm{dl}$, respectively. These results are in agreement with Almdal and Vilstrup (1988), reported that diabetic hyperglycemia fed on persimmon fruits also induces an elevation in the plasma level of creatinine, and its level is considered to be a significant marker of renal dysfunction. 
Table (1): Changes of body weight, feed intake and feed efficiency ratio of diabetic rats fed diet supplemented with persimmon fruit

\begin{tabular}{|l|c|c|c|}
\hline \multicolumn{1}{|c|}{ Parameters } & $\begin{array}{c}\text { BWG } \\
\text { G/28 day) }\end{array}$ & $\begin{array}{c}\text { FI } \\
\text { (g/day) }\end{array}$ & FER \\
\cline { 2 - 4 } Groups & Mean \pm SD & Mean \pm SD & Mean \pm SD \\
\hline G1 control $(-)$ & $50.8 \pm 2.00^{\mathrm{c}}$ & $13.00 \pm 0.84^{\mathrm{b}}$ & $0.194 \pm 0.25^{\mathrm{a}}$ \\
\hline G2 Control $(+)$ & $69.7 \pm 2.61^{\mathrm{a}}$ & $14.48 \pm 0.24^{\mathrm{a}}$ & $0.172 \pm 0.04^{\mathrm{b}}$ \\
\hline G3+2\% fruit & $53.1 \pm 2.28^{\mathrm{bc}}$ & $13.98 \pm 0.53^{\mathrm{ab}}$ & $0.136 \pm 0.13^{\mathrm{c}}$ \\
\hline G4 $+4 \%$ fruit & $54.6 \pm 2.28^{\mathrm{b}}$ & $14.32 \pm 0.26^{\mathrm{a}}$ & $0.136 \pm 0.08^{\mathrm{c}}$ \\
\hline G5 $+6 \%$ fruit & $55.3 \pm 3.69^{\mathrm{b}}$ & $14.4 \pm 0.22^{\mathrm{a}}$ & $0.137 \pm 0.05^{\mathrm{c}}$ \\
\hline LSD P $\leq 0.05$ & 1.092 & 1.18 & 0.009 \\
\hline
\end{tabular}

$\mathrm{BWG}=$ Body weight gain, $\mathrm{FI}=$ Feed intake, $\mathrm{FER}=$ Feed efficiency ratio. Mean under the same column bearing different superscript letters are different significantly at $\mathrm{P} \leq 0.05$

Table (2): Changes of organs weight in the diabetic rats fed diet supplemented with persimmon fruit

\begin{tabular}{|c|c|c|c|}
\hline \multirow{2}{*}{ Groups } & Liver (g) & Kidney (g) & Spleen (g) \\
\hline & Mean \pm SD & Mean \pm SD & Mean \pm SD \\
\hline G1 control (-) & $6.10 \pm 0.67^{b}$ & $1.25 \pm 0.190^{\mathrm{a}}$ & $0.825 \pm 0.09^{\mathrm{a}}$ \\
\hline $\mathrm{G} 2(+)$ & $7.12 \pm 0.91^{\mathrm{a}}$ & $1.25 \pm 0.170^{\mathrm{a}}$ & $0.83 \pm 0.05^{\mathrm{a}}$ \\
\hline G3+2\% fruit & $6.42 \pm 0.92^{\mathrm{a}}$ & $1.125 \pm 0.26^{\mathrm{a}}$ & $0.80 \pm 0.41^{\mathrm{a}}$ \\
\hline G4 +4\% fruit & $6.22 \pm 0.45^{\mathrm{a}}$ & $0.98 \pm 0.15^{\mathrm{a}}$ & $0.78 \pm 0.05^{\mathrm{a}}$ \\
\hline $\mathrm{G} 5+6 \%$ fruit & $6.62 \pm 0.96^{\mathrm{a}}$ & $1.13 \pm 0.45^{\mathrm{a}}$ & $0.85 \pm 0.01^{\mathrm{a}}$ \\
\hline LSD $\quad \mathrm{P} \leq 0.05$ & 1.02 & 0.86 & 1.02 \\
\hline
\end{tabular}

Mean under the same column bearing different superscript letters are different significantly at $\mathrm{P} \leq 0.05$ 
Table (3): Effect of persimmon fruit on glucose of diabetic rats

\begin{tabular}{|l|l|}
\hline Groups & $\begin{array}{l}\text { Glucose } \\
(\mathbf{m g} / \mathbf{d l})\end{array}$ \\
\hline $\mathbf{G}_{\mathbf{1}} \mathbf{C} \mathbf{( - )}$ & $96.0^{\mathrm{e}} \pm 0.70$ \\
\hline $\mathbf{G}_{\mathbf{2}} \mathbf{C ~ ( + )}$ & $198.5^{\mathrm{a}} \pm 1.10$ \\
\hline $\mathbf{G}_{\mathbf{3}}+\mathbf{2} \%$ & $117.30^{\mathrm{b}} \pm 0.50$ \\
\hline $\mathbf{G}_{\mathbf{4}}+\mathbf{4 \%}$ & $109.21^{\mathrm{c}} \pm 0.80$ \\
\hline $\mathbf{G}_{\mathbf{5}}+\mathbf{6 \%}$ & $97.53^{\mathrm{d}} \pm 0.90$ \\
\hline $\mathbf{L S D} \quad \mathbf{P} \leq \mathbf{0 . 0 5}$ & 1.53 \\
\hline
\end{tabular}

Mean under the same column bearing different superscript letters are different significantly at $\mathrm{P} \leq 0.05$

Table (4): Effect of persimmon on liver functions of diabetic rats

\begin{tabular}{|l|c|c|c|}
\hline Groups & $\begin{array}{c}\text { Parameters } \\
\mathrm{U} / \mathrm{L}\end{array}$ & $\begin{array}{c}\text { (AST) } \\
\mathrm{U} / \mathrm{L}\end{array}$ & $\begin{array}{c}\text { (ALP) } \\
\mathrm{U} / \mathrm{L}\end{array}$ \\
\hline $\mathrm{G}_{1} \mathrm{C}(-)$ & $95 \pm 1.70^{\mathrm{d}}$ & $9.22 \pm 1.10^{\mathrm{e}}$ & $6.50 \pm 0.80^{\mathrm{d}}$ \\
\hline $\mathrm{G}_{2} \mathrm{C}(+)$ & $197 \pm 0.90^{\mathrm{a}}$ & $55.82 \pm 1.35^{\mathrm{a}}$ & $20.70 \pm 0.40^{\mathrm{a}}$ \\
\hline $\mathrm{G}_{3}+2 \%$ fruit & $135 \pm 2.10^{\mathrm{b}}$ & $39.4 \pm 2.05^{\mathrm{b}}$ & $10.93 \pm 0.90^{\mathrm{b}}$ \\
\hline $\mathrm{G}_{4}+4 \%$ fruit & $105 \pm 1.10^{\mathrm{c}}$ & $31.0 \pm 0.60^{\mathrm{c}}$ & $9.20 \pm 1.20^{\mathrm{c}}$ \\
\hline $\mathrm{G}_{5}+6 \%$ fruit & $90 \pm 0.80^{\mathrm{d}}$ & $17.21 \pm 0.90^{\mathrm{e}}$ & $6.0 \pm 0.60^{\mathrm{d}}$ \\
\hline LSD P $\leq 0.05$ & & & \\
\hline
\end{tabular}

Mean under the same column bearing different superscript letters are different significantly at $\mathrm{P} \leq 0.05$ 
Table (5): Effect of persimmon fruit on the serum cholesterol and triglyceride of diabetic rats

\begin{tabular}{|c|c|c|}
\hline $\begin{array}{c}2 \\
\text { Parameters } \\
\text { Groups }\end{array}$ & $\begin{array}{c}\mathrm{TG} \\
(\mathrm{mg} / \mathrm{dl})\end{array}$ & $\begin{array}{c}\mathrm{TC} \\
(\mathrm{mg} / \mathrm{dl})\end{array}$ \\
\cline { 2 - 3 } & Mean $\pm \mathrm{SD}$ & Mean $\pm \mathrm{SD}$ \\
\hline G1 control (-) & $81.3 \pm 2.61^{\mathrm{e}}$ & $63.5 \pm 2.28^{\mathrm{c}}$ \\
\hline G2 control (+) & $223.2 \pm 2.83^{\mathrm{a}}$ & $97.0 \pm 3.69^{\mathrm{a}}$ \\
\hline $\mathrm{G} 3+2 \%$ & $169.1 \pm 2.83^{\mathrm{b}}$ & $72.6 \pm 3.41^{\mathrm{b}}$ \\
\hline $\mathrm{G} 4+4 \%$ & $153.5 \pm 3.16^{\mathrm{c}}$ & $67.5 \pm 2.61^{\mathrm{c}}$ \\
\hline G5 $+6 \%$ & $145.9 \pm 3.22^{\mathrm{d}}$ & $64.6 \pm 3.35^{\mathrm{c}}$ \\
\hline LSD $\quad \mathrm{P} \leq 0.05$ & 3.67 & 1.27 \\
\hline
\end{tabular}

$\mathrm{TG}=$ Triglyceride.

$\mathrm{TC}=$ Total Cholesterol,

Mean under the same column bearing different superscript letters are different significantly at $\mathrm{P} \leq 0.05$

Table (6): Effect of persimmon fruit on the serum lipid profiles of diabetic rats

\begin{tabular}{|c|c|c|c|}
\hline \multirow{2}{*}{ Groups Parameters } & $\begin{array}{c}\text { HDL-C } \\
(\mathrm{mg} / \mathrm{dl})\end{array}$ & $\begin{array}{c}\text { LDL-C } \\
(\mathrm{mg} / \mathrm{dl})\end{array}$ & $\begin{array}{c}(\mathrm{VLDL}) \\
(\mathrm{mg} / \mathrm{dl})\end{array}$ \\
\cline { 2 - 4 } & Mean $\pm \mathrm{SD}$ & Mean $\pm \mathrm{SD}$ & Mean $\pm \mathrm{SD}$ \\
\hline G1 control (-) & $33.3 \pm 2.61^{\mathrm{a}}$ & $13.94 \pm 3.16^{\mathrm{f}}$ & $16.26^{\mathrm{a}} \pm 0.69$ \\
\hline G2 control (+) & $23.3 \pm 3.16^{\mathrm{c}}$ & $29.06 \pm 2.28^{\mathrm{a}}$ & $44.64^{\mathrm{a}} \pm 1.20$ \\
\hline G3+2\% fruit & $27.3 \pm 2.99^{\mathrm{b}}$ & $11.48 \pm 2.98^{\mathrm{b}}$ & $33.82^{\mathrm{a}} \pm 1.72$ \\
\hline G4 $+4 \%$ fruit & $28.5 \pm 3.42^{\mathrm{b}}$ & $8.30 \pm 2.28^{\mathrm{b}}$ & $30.70^{\mathrm{a}} \pm 0.90$ \\
\hline G5 $+6 \%$ fruit & $29.7 \pm 2.61^{\mathrm{b}}$ & $5.72 \pm 2.28^{\mathrm{c}}$ & $29.18^{\mathrm{a}} \pm 2.20$ \\
\hline LSD P $\leq 0.05$ & 2.63 & 3.02 & 3.01 \\
\hline
\end{tabular}

HDL-C $=$ High density lipoprotein Cholesterol. LDL =Low density lipoprotein Cholesterol

Mean under the same column bearing different superscript letters are different significantly at $\mathrm{P} \leq 0.05$ 
Table (7): Effect of persimmon on serum urea and serum uric acid of diabetic rats

\begin{tabular}{|c|c|c|c|}
\hline $\begin{array}{c}\text { Parameters } \\
\text { Groups }\end{array}$ & $\begin{array}{c}\text { Urea } \\
(\mathrm{mg} / \mathrm{dl})\end{array}$ & $\begin{array}{c}\text { Uric acid } \\
(\mathrm{mg} / \mathrm{dl})\end{array}$ & $\begin{array}{c}\text { Serum } \\
\text { Creatinine }\end{array}$ \\
\hline $\mathrm{G}_{1} \mathrm{C}(-)$ & $42.20^{\mathrm{e}} \pm 2.10$ & $2.11^{\mathrm{b}} \pm 0.20$ & $0.87^{\mathrm{d}} \pm 0.577$ \\
\hline $\mathrm{G}_{2} \mathrm{C}(+)$ & $73.65^{\mathrm{a}} \pm 3.20$ & $3.97^{\mathrm{a}} \pm 0.90$ & $1.13^{\mathrm{a}} \pm 0.115$ \\
\hline $\mathrm{G}_{3}+2 \%$ & $50.96^{\mathrm{c}} \pm 1.60$ & $2.27^{\mathrm{b}} \pm 0.60$ & $0.99^{\mathrm{b}} \pm 0.025$ \\
\hline $\mathrm{G}_{4}+4 \%$ & $58.27^{\mathrm{b}} \pm 0.90$ & $2.60^{\mathrm{b}} \pm 0.30$ & $0.94^{\mathrm{b}} \pm 0.177$ \\
\hline $\mathrm{G}_{5}+6 \%$ & $46.25^{\mathrm{d}} \pm 0.50$ & $1.95^{\mathrm{b}} \pm 1.10$ & $0.89^{\mathrm{c}} \pm 0.030$ \\
\hline $\mathrm{LSD} \quad \mathrm{P} \leq 0.05$ & 3.24 & 1.26 & 2.14 \\
\hline
\end{tabular}

Mean under the same column bearing different superscript letters are different significantly at $\mathrm{P} \leq 0.05$ 


\section{References}

- Ahn, H.S.; Jeon, T.I.; Lee, J.Y.; Hwang, S.G.; Lim, Y. and Park, D.K. (2002): Antioxidative activity of persimmon and grape seed extract: in vitro and in vivo. Nutr Res., 22:1265-73.

- AIN (1993): American institute of nutrition purified diet for laboratory Rodent, Final Report. J. Nutrition, 123: 1939-1951 and O. Compactum Benth. J. Essential Oil Res. 8 (6): 657-664.

- Almdal, T.P. and Vilstrup, H. (1988): Strict insulin therapy normalizes organ nitrogen contents and the capacity of urea nitrogen synthesis in experimental diabetes in rats. Diabetologia, 31: 114-118.

- American Diabetes Association (2014): Diagnosis and Classification of Diabetes Mellitus. 37: P. 581.

- Azadbakhta, M.; Safapour, S.; Ahmadi, A.; Ghasemi, M. and Shokrzadeh, M. (2010): Anti-diabetic effects of aqueous fruits extract of Diospyros lotus, L. on streptozotocin-induced diabetic rats and the possible morphologic changes in the liver, kidney and heart. Journal of Pharmacognosy and Phytotherapy, 2 (2): 10-16.

- Butta, M.; Sultanb, T.; Aziza, M.; Nazc, A.; Ahmeda, W.; Kumard, N. and Imran, M. (2015): Persimmon (Diospyros kaki) fruit: Hidden phytochemicals and health clams. EXCLI Journal, 14: 542-561.

- Celik, A. and Ercisli, S. (2007): Persimmon cv. Hachiya (Diospyros kaki Thunb.) fruit: Some physical, chemical and nutritional properties. Int. J. Food Sci. Nutr., 18: 1-8.

- Chapman, D.G.; Castilla,R. and Campbell, J.A. (1959): Evaluation of protein in food. LA. Method for the determination of protein efficiency ratio.Can. J. Biochem. Physiol., 37: 679 - 686.

- Chen, V. and Ianuzzo, C.D. (1982): Dosage effect of streptozotocin on rat tissue enzyme activities and glycogen concentration. Can. J. Physiol. Pharmacol., 60: 1251-1256.

- Clinica Chimica Acta (1980): 105, 147-172, (Chemical kits).

- FAO, (2010): FAOSTAT, FAO Statiscal Databases. Downloaded from http://faostat.fao.org on 15/4/2012.

- Fonseca, V.A.; Kirkman, M.S.; Darsow, T. and Ratner, R.E. (2012): The american diabetes association diabetes research perspective. Diabetes, 6:1338-1345.

- Fossati, P. (1982): Pricipe 1. Clin. Chem., 28: 2077 (Chemical Kits).

- Friedwaid, W.T. (1972): Determination of HDL. Clin. Chem., 18: 499. (Chemical Kits). 
- George, A. P. and Redpath, S. (2008): Health and medicinal benefits of persimmon fruit: A review. Adv. Hort. Sci., 22: 244-249.

- Gorinstein, S.; Kulasek, G.W.; Bartnikowska, E.; Leontowicz, M.; Zemser, M. and Morawiec, M. (2000): The effects of diets, supplemented with either whole persimmon or phenol-free persimmon, on rats fed cholesterol. Food Chem., 70: 303-8.

- Grodon, T. and Amer, M. (1977): Determination of HDL. Clin. Chem., 18: 707. (Chemical Kits).

- Hafkenscheid, J.C. (1979): Determination of GOT. Clin. Chem., 25:155.

- Henry, R.J. (1974): Clinical Chemist: Principles and Techniques, $2^{\text {nd }}$ Edition, Hagerstoun (MD), Harcer, ROW, 882.

- Karaman, S.; Toker, Ö. S. ; Yüksel, F.; Çam, M.; Kayacier, A. and Dogan M. (2014): Physicochemical, bioactive, and sensory properties of persimmon-based ice cream: technique for order preference by similarity to ideal solution to determine optimum concentration. Journal of Dairy Science, 97 1: 97-110,

- Kim, Y.J. and Yokozawa, T. (2009): Modulation of Oxidative Stress and Melanogenesis by Proanthocyanidins. Biol. Pharm. Bull., 32: 11559.

- Lee, R. and Nieman, D. (1996): Nutrition Assessment. $2^{\text {nd }}$ Ed. Mosby, Missouri, U.S.A.

- Matsumoto, K.; Watanabe, Y.; Ohya, M.A. and Yokoyama, S. (2006): Young Persimmon Fruits Prevent the Rise in Plasma Lipids in a Diet-induced Marine Obesity Model. Biol. Pharm. Bull., 29: 2532-5.

- Moss, D.W. (1982): Alkaline phosphatase isoenzymes. Clin. Chem. 28: 2007-2016.

- Ozgen, M. ; Serce, S. and Kaya, C. (2009): Phytochemical and antioxidant properties of anthocyanin-rich Morus nigra and Morus rubra fruits. Sci, Horticult. Amsterdam, 119: 275-279.

- Patton, C.J. and Crouch, S.R. (1977): Enzymatic determination of urea. J. of Anal. Chem., 49: 464-469.

- Quan, N.; Kobayashi, K.; Matsunami, Y.; Ide, M.; Makarova, M.; Shen, L.; Ohno, S.; Zheng, Y.; Kobayashi, H.; Lopez, L. R. and Matsuura, E. (2012): Persimmon (Diospyros Kaki Thunb 'Saijo') peel improved dyslipidemia and its related production of atherogenic autoantigen complexes in low density lipoprotein receptor-deficient mice. Open Nutr. J., 6: 12-20. 
- Rowley, W.R. and Bezold, C. (2012): Creating public awareness: State 2025 diabetes for recasts. Population Health Management, 15 (4): 194-200.

- Sachan, N.K.; Kumar, Y.; Pushkar, S.; Thakur, R. N.; Gangwar, S - S and Kalaichelvan, V. K. (2009): Anti-diabetic potential of alcoholic and aqueous extracts of Ficus racemosa, Linn. Bark in normal and alloxan induced diabetic rats. International Journal of Pharmaceutical Sciences and Drug Research, (1): 24 - 27.

- SAS (1988): SAS Users Guide: Statistics version $5^{\text {th }}$ Ed. SAS. Institute Inc., Cary N.C.

- Schermer (1967): The Blood Morphology of Laboratory Animal. Longmans, Printed in Great Britain, Green and Co. Ltd., pp.350.

- Sharma, U.; Sahu, R.; Roy, A. and Golwala, D. (2010): In vivo antidiabetic and antioxidant potential of Stephania hernandifolia in streptozotocin induced-diabetic rats. J. Young Pharm., (2): 255-260.

- Sochar, M.; Baquer, N.Z. and Mclean, P. (1985): Glucose underutilization in diabetes: Comparative studies on the changes in the activities of enzymes of glucose metabolism in rat kidney and liver. Mol. Physiol., 7: 51-68.

- Thomas, L. (1992): Labor and Diagnose, $4^{\text {th }}$ Ed. Marburg: Die Medizinischi Verlagsgesellschaft, (Chemical Kits).

- Tinder, P. (1969): Determination of triglycerides, Ann. Clin. Biochem., 6: $24-27$.

- Yaqub, S.; Farooq, U.; Shafi, A.; Akram, K.; Murtaza, M.; Kausar, T. and Siddique, F. (2016): Chemistry and functionality of bioactive compounds present in Persimmon. Journal of Chemistry, 5: 1-13.

- Young, D. (1975): Effects of drugs on clinical laboratory tests. Pestaner, L. Clin. Chem., 21: 5, 1D-432D, (Chemical Kits). 